\title{
Electoral Incongruence and Delayed Republican Gains in Southern State Legislatures
}

\author{
Adam Myers \\ Providence College
}

\begin{abstract}
This paper investigates the impact of electoral incongruence - the tendency of Democratic state legislative candidates to perform better than their co-partisans in higher-level races - on partisan control of southern legislative chambers in the 1990s and 2000s. Using precinct-level data from five southern states, I examine incongruence between presidential and state house election results and show how such incongruence delayed the Republican consolidation of power in southern legislatures during this period. I then develop and test an account of electoral incongruence focusing on the tendency of older white southerners and those living in rural areas to split their tickets across state and federal offices, particularly when given the option of voting for conservative Democratic legislative incumbents. Lastly, I explore possible reasons for electoral incongruence's recent decline. The results of the paper provide important insights concerning the delayed Republican takeover of southern legislatures, an underexplored aspect of southern partisan change. They also speak to longstanding questions in the state politics literature about the extent of autonomy that state party systems can hope to enjoy in a highly nationalized era.
\end{abstract}

In the ongoing story of partisan change in the American South, the 1990s and 2000s stand out as a disjointed era. When only federal elections are considered, these two decades can collectively be viewed as the period in which Republican majority status in the region became an undeniable reality. During the decades leading up to the 1990s, Republicans occupied a growing but still minority share of southern congressional seats while their party's presidential candidates often won the electoral votes of most southern states. Over the course of the 1990s and 2000s, however, Republicans came to occupy a large majority of southern congressional seats and GOP strength in the South became so entrenched that even a southern presidential candidate (i.e, Al Gore in 2000) couldn't win his home state as a Democrat. Thus, by the end of the first decade of the $21^{\text {st }}$ century, nearly all observers of national politics agreed that the South was Republican territory, with some going as far as to suggest that Democrats should skip the region entirely in their quest for a national majority (see, e.g., Schaller 2008).

The notion that the South was a Republican stronghold during the 1990s-2000s is far more questionable if one focuses on party politics in southern statehouses rather than in Washington, DC. When state politics - and, in particular, state legislative politics - is the vantage point, the 1990s and 2000s do not appear as the era in which Republican power in the region was consolidated, but instead as a time period in which the Democratic hold on the region began to unravel but did not fully do so. After the 1994 elections, in which Republicans won control of a majority of southern U.S. House seats for the first time, Democrats maintained control of 19 of the 22 southern state legislative chambers, and in many cases the margin of control was overwhelming (Aistrup 1995). After the 2004 presidential election, in which Republican George W. Bush easily won the electoral votes of every single southern state, Democrats maintained control of 11 of the 22 southern legislative chambers. Even in southern legislative chambers where Republicans had captured control by 2004 , their grip on power was generally quite weak.

The disparity between Republican successes in federal and state elections during the 1990s-2000s might be attributed to two basic factors. First, Republican gains in southern state 
legislative elections during this time period were likely slowed by the failure of Republicans to contest many state legislative races, including more than a few occurring in areas that supported GOP candidates for higher offices. Second, even where Republicans were successful in contesting state legislative races, Democratic candidates may have performed much better than their co-partisans further up the ticket. Of these two factors, the issue of electoral contestation has received by far the largest share of scholarly attention. ${ }^{1}$

While not dismissing the importance of electoral contestation, this paper takes up consideration of the second factor, which I follow Gimpel (1996) in calling electoral incongruence. Using an original dataset of precinct-level electoral and demographic data from five southern states (South Carolina, Texas, North Carolina, Georgia, and Oklahoma), I examine the nature and extent of incongruence between presidential and contested state legislative election results, finding clear evidence that such incongruence was a crucial factor in the delayed ascendancy of Republicans in southern state legislative chambers. Beyond merely demonstrating the impact of electoral incongruence, I propose and test an explanation of its existence and consider possible reasons for its recent decline.

The paper proceeds as follows. First, I provide an overview of the extant literature on the staggered nature of Republican gains in the South, showing that the bulk of existing scholarship explaining the staggered pattern has focused on electoral contestation rather than electoral incongruence. Utilizing several statistical and visual indicators, I then compare presidential and state house election results (at both the precinct and district level) for the relevant time period in the five states, documenting both the independent impact of electoral incongruence in delaying Republican gains throughout the 1990s and 2000s as well as the decline in electoral incongruence in each state that has transpired across recent election cycles.

Turning to explaining the persistence of electoral incongruence in the South during the 1990s-2000s, I propose an explanation of electoral incongruence in the American South that focuses on the tendency of older, rural white southerners in this era to split their tickets across federal and state legislative offices. I then test a series of hypotheses derived from this explanation using multivariate analyses incorporating electoral and demographic data at the precinct level. My analyses provide significant support for my theory, demonstrating that the demographic makeup of a precinct (in particular, the interaction between its racial and age breakdowns) as well as a variety of incumbency-related factors all bear significantly upon the extent of electoral incongruence across precincts or districts. Following these analyses, I consider the complicated question of why electoral incongruence in the South has plummeted in recent years, exploring the voluntary retirement of incumbent Democratic state legislators, the growing nationalization of state legislative elections, and the effects of legislative redistricting following the 2010 Census as possible contributing factors.

This article offers findings that are of substantive and theoretical importance for a variety of areas in the study of American politics. First and foremost, the study sheds considerable light on the recent Republican consolidation of power in southern state legislatures, an underexplored aspect of southern partisan change whose consequences have been made apparent by numerous policy developments in southern statehouses now under unified GOP control. Additionally, the article uncovers both the causes and consequences of electoral incongruence, a longstanding feature of southern politics that has never before received a rigorous analysis. Beyond merely 
being of interest to southern politics scholars, however, the study also speaks to broader questions that scholars of American state politics and federalism have been asking about the extent to which state party systems can and do enjoy autonomy from national politics in the modern era. More specifically, its results show the mechanisms by which the state party systems of the southern states have recently lost the autonomy they enjoyed from national politics in the 1990 s and 2000s, and help to explain why it is highly unlikely that the relatively high degree of state party system autonomy that existed in the region during this period could be matched in the future, in the South or elsewhere.

\section{Extant Explanations of the Delayed Republican Ascendancy in the American South}

Students of southern politics have long been interested in the staggered nature of partisan change in the region, a process referred to by a variety of names, including "creeping realignment" (Bullock 1988), "top-down advancement" (Aistrup 1996), and "split-level realignment" (Lublin 2004, p. 68). The basic contours of this process are well-known: Republican gains in the South initially took root in presidential elections during the 1950s and 1960 s, became manifest in gubernatorial and senatorial elections during the 1970s and 1980s, made their way to congressional elections during the 1980s and 1990s, and finally penetrated state legislative elections in the 1990s and 2000s.

Scholars who have written about the staggered nature of Republican gains in the South have provided a variety of explanations for the phenomenon. While these explanations vary, the vast majority of them have emphasized differences in rates of Republican electoral contestation across offices at higher and lower levels. Thus, in one of the earliest accounts of staggered partisan change in the South, Bullock (1988) hypothesizes that viable Republican candidates in the region were more likely to emerge in contests for more significant offices serving larger constituencies. Aistrup (1996) builds on Bullock's insights by arguing that the campaigns of Republican presidential candidates in the 1950s and 1960s functioned as catalysts for the emergence of GOP candidates further down the ballot. In the process of actively contesting the southern states, he contends, Republican presidential campaigns provided resources for nascent state Republican organizations and developed a dependable base of state-level GOP party activists and donors, thereby encouraging conservative southerners to run for statewide offices and later for U.S. House as Republicans. Like Aistrup, Lublin (2004) emphasizes the inability of state Republican parties to recruit state legislative candidates as being a primary reason for the comparatively slow nature of Republican gains in state legislative elections. ${ }^{2}$ Beyond focusing on Republican candidate emergence squarely as an independent variable, these and other scholars have also considered how a variety of ancillary processes (including the implementation of term limits and changes in redistricting practices) helped to foster conditions in which Republicans were more likely to contest state legislative races, thereby eventually leading to GOP gains in statehouses.

Given the strong findings in much of the aforementioned work, there can be little doubt that low rates of Republican electoral contestation served to slow the speed of Republican gains in southern statehouses. Still, there is another, less-studied potential mechanism that may have had the same effect. That mechanism has to do with the possibility that, in those state legislative races that Republicans managed to contest, Democrats performed better than their co-partisans in 
higher races. To be sure, this mechanism has been occasionally acknowledged by scholars of southern politics, but it has never been examined rigorously. For example, in his illuminating work, Lublin does suggest that numerous white southerners throughout the 1980s and 1990s may have voted for Republican candidates in federal contests and Democratic candidates in state contests. He does not, however, appear to test this claim or speculate about the factors that might eventually overwhelm the pattern to which he points.

In considering what previous scholars have had to say about electoral incongruence in the South, it is important to distinguish it from a related but nonetheless distinct concept that has occasionally been advanced in the literature on southern politics: dual partisanship (Converse 1966, Hadley 1985, Barth 1992). Dual partisanship is the notion that white southerners in the late $20^{\text {th }}$ century may have identified with different political parties in reference to state and national politics. The results of the handful of studies that have empirically examined the possibility of dual partisanship in the South cast some doubt on its utility for explaining partisan change in the region. The concept of electoral incongruence, however, differs from dual partisanship in that its focus is on electoral outcomes rather than party identification. As Lublin points out, a divergence in voting patterns for state and federal offices could be the result of factors other than distinct attitudes toward state and national politics. He goes on to suggest that "differences in...candidate offerings" may be one such factor (69). In other words, electoral incongruence may have occurred not because southern voters intrinsically favored Democrats for state offices and Republicans for federal offices, but rather because voters consistently recognized Democratic state legislative candidates as being more conservative than Democratic candidates for president or even the U.S. Congress.

The notion that ideological differences among Democratic candidates may have caused southerners to split their tickets across federal and state offices dovetails nicely with the findings of studies examining national patterns in the incumbency advantage and ticket-splitting in particular. Previous studies of ticket-splitting between presidential and congressional elections suggest that most American ticket-splitters do not split their tickets for institutional reasons (i.e., a desire to balance power between the legislative and executive branch), but rather because of their personal awareness or knowledge of a congressional candidate (Burden and Kimball 1998; Bean and Wattenberg 1998; but see Lewis-Beck and Nadeau 2004). The logic behind this finding can also be applied to the phenomenon of ticket-splitting between presidential and state legislative races. Given Americans' general lack of knowledge about state government and intergovernmental relations (see, e.g., Key 1956, Delli Carpini and Keeler 1996), it is unlikely that a deep interest in state politics or institutional concerns related to federalism are at the heart of why Americans (southerners and non-southerners alike) split their tickets across offices at different levels of government. Far more likely is the notion that ticket-splitting across federal and state offices occurs when voters recognize a candidate for state office as being ideologically different from a candidate for federal office. This is especially likely to be the case when the candidate for state office is an incumbent who is well-known and has an established track record (Cox and Morgenstern 1993; Carey, Niemi, and Powell 2000). 


\section{Electoral Incongruence in the American South: The Macro Evidence}

The analyses of this paper focus on five southern states: South Carolina, Texas, Georgia, North Carolina, and Oklahoma. This sample of states is fairly representative of the southern region, in that it includes two Deep South states (Georgia and South Carolina), two Rim South states (Texas and North Carolina), and one state on the southern fringe (Oklahoma). ${ }^{3}$ Electoral incongruence is measured as the difference between state legislative election results and presidential election results. Presidential election results serve as the most useful benchmark for measuring electoral incongruence since Republican success in presidential elections in the South is thought to have been the initial trigger of the region's staggered realignment (Aistrup 1996). Moreover, since the U.S. presidency is a nationally-elected office, using presidential election results ensures that the benchmark for assessing electoral incongruence is uniform across districts and states. ${ }^{4}$

As a first step toward demonstrating the existence of substantial incongruence between presidential and state legislative elections in the South during the 1990s and 2000s, I present Figure 1 (next page), which displays scatterplots of presidential and state house results in contested precincts in each of the five states for presidential election years between 1996 and 2012. ${ }^{5}$ Data are arranged by row according to state and by column according to year. In each scatterplot, the $\mathrm{x}$-axis represents the Democratic share of the two-party vote for president in a given precinct, and the $y$-axis represents the Democratic share of the two-party vote for state representative in that precinct. Pearson correlation coefficient $(\rho)$ values are included as summary measures of the relationship between these two variables. 
Figure 1: Incongruence between Precinct-Level Presidential and State House Election Results in Five Southern States, 1996-2012
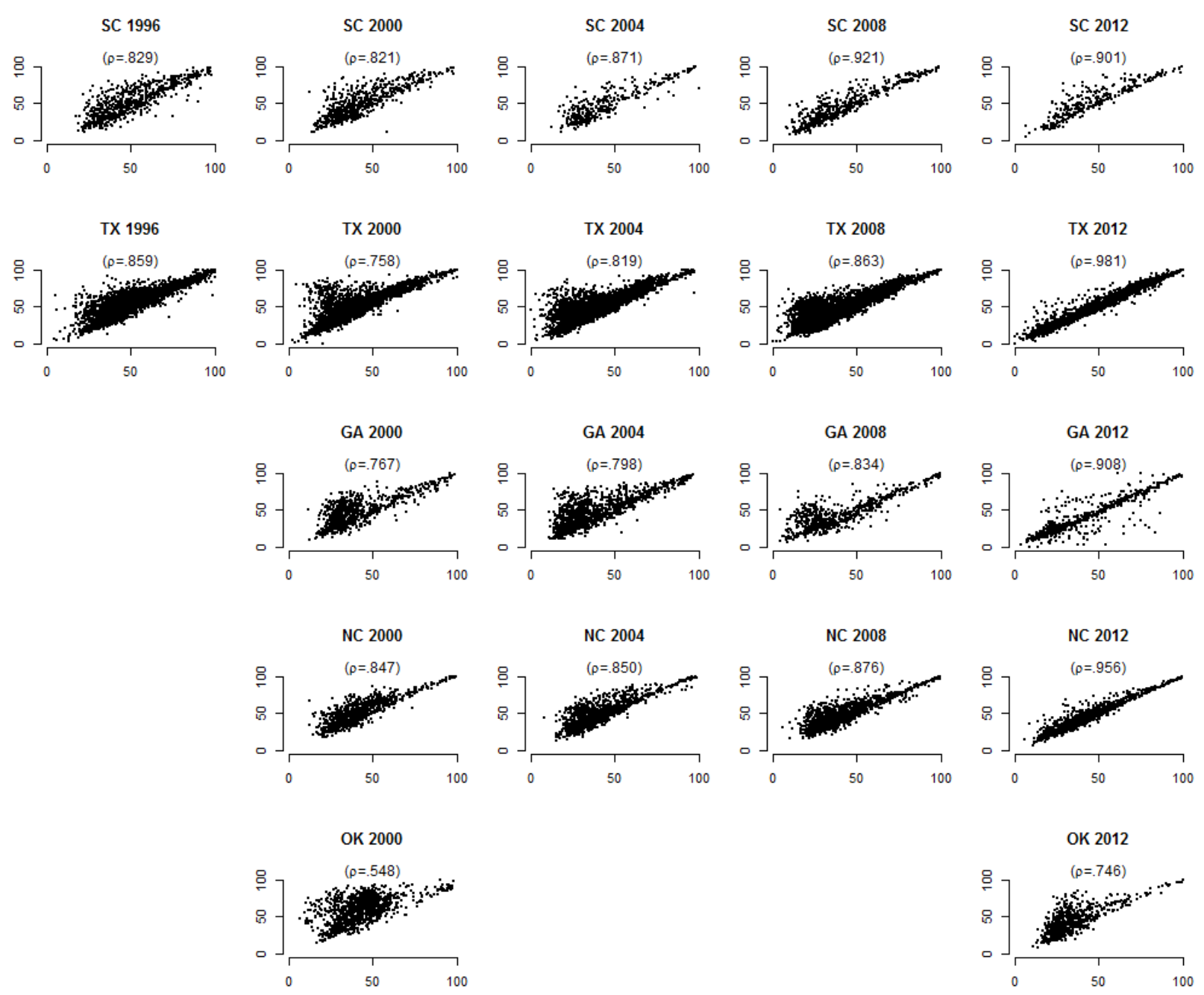

$(\mathrm{X}$-Axis $=$ Dem Share of Two-Party Presidential Vote; Y-Axis $=$ Dem Share of Two-Party State House Votes $)$ 
Scanning across the rows in Figure 1, one notices a very similar pattern: the relationship between presidential and state legislative election results is consistently much stronger by the end of the period at hand than at the beginning. In each of the states displayed in the figure, the scatterplots for the 1996 or 2000 elections reveal a large swath of observations that defy the strong linear relationship that characterizes the bulk of the precincts. These observations tend to lie in the upper-left quadrant of each graphic; in other words, they represent precincts in which Democratic state legislative candidates performed much better than their co-partisans at the top of the ticket. By the 2012 elections, however, such precincts are practically non-existent in every state except Oklahoma, and the overall relationship between the two variables in the scatterplots approaches collinearity as a result. In Oklahoma as well, the presence of such precincts is substantially reduced, though the Sooner State is clearly the laggard in the trend of growing congruence between presidential and state legislative election results.

When considered as a whole, Figure 1 strongly suggests that electoral incongruence was widespread in the American South during the 1990s-2000s and that it declined substantially toward the end of that period. The mere existence of some amount of electoral incongruence throughout the 1990s and 2000s may not be of major consequence, however. The importance of electoral incongruence lies in the extent to which it impeded Republican victories in southern state legislative elections throughout the 1990s and 2000s. Indeed, it is possible that electoral incongruence only had the effect of shrinking (as opposed to eliminating) the margins of victory of Republican state legislative candidates running in districts whose voters overwhelmingly supported Republicans presidential candidates. It is also possible that electoral incongruence had some effect in delaying Republican gains, but that the magnitude of this effect pales in comparison to the effect of Republican non-contestation of districts supporting GOP presidential candidates. To determine the extent to which both of these factors prevented Republican state legislative victories, I aggregate precinct-level presidential vote totals to the state house district level for the five states in my analyses. ${ }^{6}$ Combining district-level presidential election returns with district-level state legislative election returns, I am able to determine the percentages of districts Republicans failed to capture due to both electoral incongruence and Republican noncontestation.

Figure 2 (next page) displays bar charts showing the percentage of seats held by Democrats in the five state house chambers examined in this manuscript after each presidential election from 1996 to 2012 (in the cases of South Carolina and Texas) or 2000 to 2012 (in the cases of Georgia, North Carolina, and Oklahoma) . Each column in the bar chart is divided into three segments, with the lowest segment representing districts won by Democratic state house candidates as well as Democratic presidential candidates (electoral congruence), the middle segment representing districts that Democratic presidential candidates lost but that Democratic state house candidates won because Republicans did not contest them (GOP non-contestation), and the upper segment representing districts that Democratic presidential candidates lost at the same time as Democratic state house candidates defeated Republican state house candidates (electoral incongruence). 
Figure 2: Percentages of Seats Held by Democrats in the Lower Legislative Chambers of Five Southern States, 1996-2012
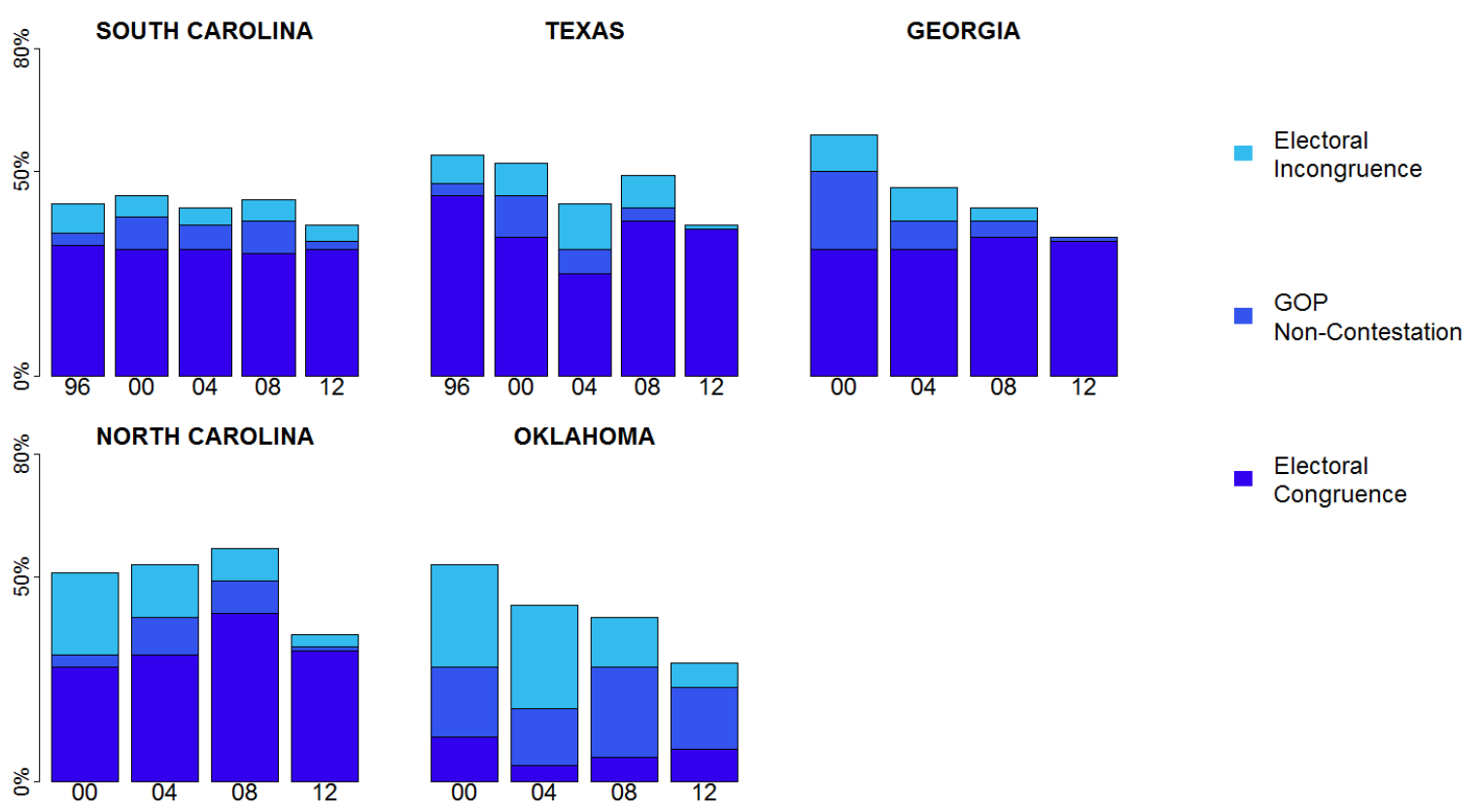

OKLAHOMA

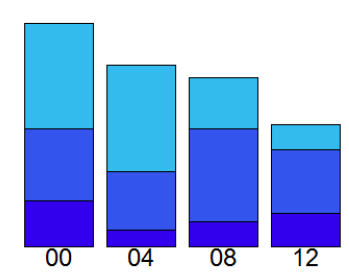

A close examination of Figure 2 reveals that Democrats controlled the lower chamber of every state in the sample except South Carolina following the 2000 elections, and that Democrats would not have been able to maintain control of any of these chambers absent electoral incongruence. In Texas, for example, Democrats defeated Republican challengers in $8 \%$ of the state house districts at the same time as their party's nominee for president lost these same districts. Had the outcomes of the state house races in these districts been congruent with the district-level presidential election results, Democratic candidates would have only won $44 \%$ of Texas house seats instead of 52\%, and Republicans would have gained control of the Texas House of Representatives in that election. ${ }^{7}$ The same can be said for North Carolina, Georgia, and Oklahoma. In each of these states, removing the upper segment of the bar corresponding to the 2000 election in Figure 2 would cause the overall height of that bar to drop below the 50\% mark. Using this same logic to assess the other elections represented in the figure, one can see that electoral incongruence prevented the Republican takeover of the Texas House as early as 1996 and that it prevented the takeover of the North Carolina House through 2008. In Texas, Georgia, and especially Oklahoma, Democrats narrowly lost control of lower legislative chambers in the early 2000s, but without electoral incongruence, their influence in these chambers would have been reduced much further.

Comparing the sizes of the bar segments representing electoral incongruence and Republican non-contestation in Figure 2, one can also see that the relative effect of electoral incongruence vis-à-vis Republican non-contestation varies across elections and states. While 
Republican non-contestation appears to have been somewhat more important overall in delaying Republican gains in Georgia, electoral incongruence appears to have played the greater overall role in Texas, North Carolina, and Oklahoma. ${ }^{8}$ In all five states, electoral incongruence registers a clear and significant effect on the partisan breakdown inside southern state legislatures, at least during the early part of the time period on display.

This effect, however, does not persist across the entire time period. By 2012, the bar segments representing both electoral incongruence and Republican non-contestation have shrunk dramatically across all five states, and in some cases they have disappeared completely. In the lower chambers of South Carolina, Texas, Georgia, and North Carolina, districts won by Barack Obama in 2012 account for nearly all of the seats held by Democrats after that election. The only state in the sample in which electoral incongruence and Republican non-contestation register a substantial effect in 2012 is Oklahoma, but if the trajectory that the Oklahoma House has been on between 2000 and 2012 continues, neither of these factors is likely to have much influence over the partisan breakdown of that chamber for much longer.

\section{Explaining Electoral Incongruence in the American South}

Having established the importance of electoral incongruence in delaying Republican gains in southern state legislatures, I now turn to explaining its existence in the 1990s and early 2000s. Doing so requires the development of an account of how the individual voting decisions made by southerners during this time period could have resulted in the aggregate voting patterns previously documented. The explanation I develop focuses on the interaction between two factors in encouraging ticket-splitting across state and federal offices: 1) cross-pressures felt by older white southerners and those living in rural areas, many of whom maintained their ancestral affiliation with the Democratic Party despite their ideological proximity to the national Republican Party; 2) the advantage that longstanding conservative Democratic lawmakers enjoyed among their constituents.

As is well-known, prior to the $1960 \mathrm{~s}$, the vast majority of white southerners identified with the Democratic Party, but in the last decades of the $20^{\text {th }}$ century, the percentage of white southerners identifying as Democrats declined substantially (Petrocik 1987; Knuckey 2006; McKee 2010). This decline, primarily driven by a desire to align party affiliation with ideological orientation (see, e.g, Abramowitz and Knotts 2006), resulted in Republicans becoming the majority party of white southerners by the end of the $20^{\text {th }}$ century. Not all southern whites were equally likely to have changed their party identifications, however. Throughout the late $20^{\text {th }}$ century, older whites (especially those who came of age before the 1960s) and rural whites were much less likely to become Republicans than other white southerners (Knuckey 2006; Hayes and McKee 2007). For many in these two sub-groups, ancestral affiliation with the Democratic Party outweighed ideological alignment with the national Republican Party for a surprisingly long amount of time.

Given that the ideologies of Democratic presidential nominees throughout the 1990s and early 2000s tended to differ vastly from those of most white southerners, it should come as no surprise that defection toward Republican presidential candidates among white southerners who continued to identify as Democrats during this era was quite high (Hillygus and Shields 2008). Such defection is less likely to have occurred in state legislative elections, where the minimal 
evidence that exists suggests that the Democratic Party continued to nominate candidates with conservative ideologies befitting the constituencies of their districts (see, e.g., Shor and McCarty 2011). When presented with such nominees, conservative Democratic voters in the South would have had little reason to defect from their party. Thus, rather than voting exclusively for one party or the other, such voters may well have split their tickets between Republican candidates for president and Democratic candidates for state representative.

A second factor that may have fostered high levels of electoral incongruence in southern states throughout the 1990s and early 2000s was the fact that a good portion of Democratic nominees for state legislature during this time period were longstanding incumbents who had established deep connections with their constituencies (Lublin 2004). Strong ties to the residents of their districts may have allowed these veteran lawmakers to cultivate a "personal vote" that assisted them in withstanding electoral tides favoring the Republican Party (Petrocik and Desposato 2004). Additionally, through their voting records at the statehouse, many of these incumbents likely established their conservative bona fides, which may have assisted them in reassuring conservative voters in their districts who had become suspicious of Democratic politicians at all levels of government. For both of these reasons, ticket splitting across state and federal offices is more likely to have occurred in districts in which Democratic incumbents (especially conservative ones) were running for re-election.

The foregoing account of electoral incongruence in the South suggests a number of hypotheses about the circumstances yielding high levels of electoral incongruence. First, it suggests that electoral incongruence should be high in areas of the South with large concentrations of conservative Democratic voters who had resisted becoming Republicans throughout the late $20^{\text {th }}$ century. Though detailed geographical data on party identification and ideology from the 1990s and early 2000s are unavailable, Census geographical data on age and urban/rural location (two demographic variables that, as discussed above, are associated with delayed party switching among conservative southern whites) can be considered in their stead. Thus, the first two hypotheses are as follows:

- Hypothesis \#1: Areas with higher shares of older white voters will exhibit higher levels of electoral incongruence.

- Hypothesis \#2: Areas with higher shares of rural voters will exhibit higher levels of electoral incongruence.

The account of electoral incongruence also suggests that electoral incongruence should be highest where incumbent Democrats are running for re-election, especially if these incumbents have compiled conservative voting records. Thus, the next two hypotheses are as follows:

- Hypothesis \#3: Districts in which incumbent Democratic lawmakers are running for reelection will exhibit higher levels of electoral incongruence.

- Hypothesis \#4: Among districts in which incumbent Democratic lawmakers are running for re-election, the more conservative the incumbent Democrat, the higher the level of electoral incongruence. 


\section{Testing the Account of Electoral Incongruence}

In this section of the paper, I test the four aforementioned hypotheses (and thus the overarching account from which they are drawn) using an original dataset of precinct-level electoral and demographic data from the year 2000 for each of the five states included in the study. ${ }^{9}$ Electoral incongruence (the dependent variable) is measured as the difference between the Democratic share of the two-party state legislative vote and the Democratic share of the twoparty presidential vote within precincts. Hence, high positive values indicate that Democratic state legislative candidates performed far better than their counterparts in presidential elections, high negative values indicate that they performed far worse, and values close to zero indicate little to no incongruence. As in previous sections of the paper, the observations include all unsplit precincts inside single-member state house districts featuring contested races (in this case in the 2000 election).

Because precincts are created by local authorities and are often not coterminous with any geographical unit of the U.S. Census, Census-based demographic data at the precinct level are not readily available and need to be estimated. For this project, such data were estimated by intersecting precinct boundaries with Census block group boundaries using ArcGIS and then apportioning Census block group demographic data to precincts based on the extent of geographical overlap between the two areal units. Details explaining this process, as well as some tests that were taken to ensure the validity of the estimates, are discussed in the appendix.

The independent variables in the analyses include:

- The percentage of the voting-eligible population (over 18 years of age) that is white and between ages 18 and 64 .

- The percentage of the voting-eligible population that is white and aged 65 and over.

- The percentage of precinct residents who live in rural areas as defined by the Census.

- Two incumbency-related dummy variables, one indicating whether a precinct was located in a district contested by an incumbent Democrat $(1=\mathrm{YES} ; 0=\mathrm{NO})$ and the other indicating whether it was contested by an incumbent Republican $(1=\mathrm{YES} ; 0=\mathrm{NO})$.

- Two terms interacting the incumbency dummy variables with incumbents' ideology, as measured by Shor and McCarty (2011). Shor and McCarty's data range from (roughly) -2 to 2 , with higher values indicating a more conservative ideology, and were adjusted slightly to give the mean American legislator a value of $0 .{ }^{10}$ Thus, a precinct inside a district contested by a Democratic incumbent with an adjusted ideology score of -1.5 (very liberal) would receive a Democratic incumbent-ideology interaction score of $1 *$ $-1.5=-1.5$ and a Republican incumbent-ideology interaction score of $0 *-1.5=0$, which is the mean nationwide ideology score on the adjusted scale. A precinct inside a district contested by a Republican incumbent with an ideology score of 1.3 (very conservative) would receive a Democratic incumbent-ideology interaction score of $0 * 1.3=0$ and a Republican incumbent-ideology interaction score of $1 * 1.3=1.3$. Lastly, a precinct inside an open-seat state legislative race would receive a value of 0 for both interaction terms. ${ }^{11}$

A table showing descriptive statistics for all of the variables used in the multivariate analysis are presented in the appendix. 
In choosing the correct model specification, it is important to note the data's multilevel structure. Precincts are nested within state legislative districts, and some of the variables (the dependent variable and the demographic independent variables) are measured at the precinct level while others (the incumbency-related independent variables) are measured at the district level. Given this structure, a multilevel linear model is an appropriate way to prevent a violation of the independence-of-errors assumption in conventional ordinary least squares (OLS) analysis (Steenbergen and Jones 2002). Thus, I employ a varying-intercept multilevel model in which the constant term is allowed to vary across state house districts (Gelman and Hill 2007). ${ }^{12}$

The results of this analysis are shown in Table 1 (next page). Examining both the precinct-level and the district-level fixed effects, one finds strong support for my hypotheses. Regarding the precinct-level effects, the table shows that, while both the percentage of whites between ages 18 and 64 and the percentage of whites over age 65 produce highly significant, positive effects on electoral incongruence, the magnitude of the effect of the latter is over three times as large as that of the former. The analyses also show that the percentage of rural residents in a precinct yields a fairly large and highly significant effect in the expected (positive) direction. Regarding the district-level effects, the Democratic incumbency dummy and the Democraticincumbency-ideology interaction term both yield large, positive, and highly significant coefficients, as my hypotheses predict. As the table shows, the presence of a Democratic incumbent results in an average increase in electoral incongruence of $11.59 \%$, and a one-point increase in conservative ideology among Democratic incumbents (roughly speaking, an ideological shift equivalent in magnitude to moving from a highly left-wing ideology to a centerright ideology) results in an average increase in electoral incongruence of $8.49 \%$. On the other hand, the Republican incumbency dummy and the Republican incumbency-ideology interaction do not yield large coefficients. Clearly, the impact of incumbency-related factors on electoral incongruence in the South is much more palpable among Democratic incumbents than among Republican ones. 
Table 1: Estimates of Varying-Intercept Multilevel Model Predicting Electoral Incongruence in Contested Precincts of Five Southern States, 2000

Variable

Precinct-level fixed effects

(Intercept)

$\%$ white and aged 18-64 (among eligible voters)

$\%$ white and aged 65 and over (among eligible voters)

$\%$ rural

District-level fixed effects

Democratic incumbent

Democratic incumbent * incumbent ideology

Republican incumbent

Republican incumbent * incumbent ideology
Coefficient (SE)

$0.05(0.01)^{* * *}$

$0.16(0.02)^{* * *}$

$0.05(0.00)^{* * *}$
$8.49(2.16)^{* * *}$

$-5.72(3.29)^{*}$

$0.87(2.86)$

Random effects

District-level variance component

0.65

Residual variance component

$\mathrm{n}$ (precincts)

0.46

$\mathrm{n}$ (districts) 5,405

AIC 238

$* \mathrm{p}<.05$

$* * \mathrm{p}<.01$

$* * * \mathrm{p}<.001$

Though the results of Table 1 provide important support for my hypotheses, it is possible that these results reflect relationships that exist only in some of the states in my sample but not others. To examine whether the results in Table 1 are consistent across the five states, I ran separate multilevel regressions for the observations from each state. The results of these statebased analyses are displayed in Table 2 (next page). 
Table 2: Estimates of State-Level Varying-Intercept Multilevel Models Predicting Electoral Incongruence Pct-level fixed effects

South Carolina Texas Georgia North Carolina Oklahoma

$\begin{array}{llllll}\text { (Intercept) } & -4.4(3.8) & 1.9(2.7) & 1.6(2.9) & 1.8(2.4) & -7.8(3.9) \\ \text { \% white, 18-64 } & 0.10(0.02)^{* * *} & 0.02(0.01)^{*} & 0.13(0.02)^{* * *} & 0.02(0.02) & 0.08(0.03)^{* * *} \\ \text { \% white, 65+ } & 0.16(0.05)^{* * *} & 0.10(0.03)^{* * *} & 0.11(0.06) * & 0.18(.04)^{* * *} & 0.40(0.05)^{* * *} \\ \text { \% rural } & 0.04(0.01)^{* * *} & .04(0.01)^{* * *} & 0.04(0.01)^{* * *} & 0.06(.01)^{* * *} & 0.08(0.01)^{* * *}\end{array}$

Dist-level fixed effects

$\begin{array}{llllll}\text { Dem. inc } & 8.93(4.78)^{*} & 16.1(3.2)^{* * *} & 17.2(3.9)^{* * *} & 4.0(3.6) & 12.0(3.9)^{* * *} \\ \text { Dem. inc. * ideo } & -4.04(9.03) & 12.0(2.6)^{* * *} & 33.8(7.5)^{* * *} & -2.5(5.2) & 4.6(7.1) \\ \text { GOP inc. } & -1.38(17.0) & -3.9(9.0) & -8.9(5.7) & -4.1(4.5) & -24.3(13.4)^{*} \\ \text { GOP inc * ideo } & -1.55(19.44) & 1.0(6.7) & 1.3(5.2) & -0.9(4.5) & 13.7(10.5)\end{array}$

Random effects

\begin{tabular}{llllll} 
Dist var. comp. & 1.10 & 0.33 & 0.57 & 0.29 & 0.80 \\
Resid. var. comp. & 0.43 & 0.45 & 0.41 & 0.37 & 0.53 \\
$\mathrm{n}$ (precincts) & 524 & 2287 & 663 & 793 & 1138 \\
$\mathrm{n}$ (districts) & 41 & 42 & 58 & 39 & 58 \\
\hline$*=\mathrm{p}<.10$ & $* *=\mathrm{p}<.05$ & $* * *=\mathrm{p}<.01$ & &
\end{tabular}


With respect to the precinct-level fixed effects, a close examination of Table 2 reveals a generally consistent set of relationships that comport with the findings of the cross-state analysis displayed in Table 1. In particular, the age-race variables produce coefficients that are in the expected (positive) direction, and in every state except Georgia, the magnitude of the coefficient for the percentage of whites over age 65 greatly exceeds the magnitude of the coefficient for the percentage of whites between ages 18 and 64. Moreover, across all five states, the coefficients for the percent-rural variable are positive, highly significant, and similar in magnitude.

While the precinct-level fixed effects are quite consistent across states, the district-level fixed effects do evince some variation. For example, the Democratic incumbency coefficient is fairly large and significant in four of the five states, but in North Carolina it registers a small and statistically insignificant effect. The aberrational results for North Carolina are likely related to the fact that the sample of North Carolina precincts excludes precincts located in multimember house districts (as discussed earlier). Because multimember districts in the pre-2002 North Carolina House were often represented by longstanding conservative Democratic lawmakers, the omission of precincts inside multimember districts from the North Carolina dataset likely works to decrease the size and significance of the Democratic incumbency variable.

Additionally, the size of the coefficient for the term interacting Democratic incumbency and incumbent ideology differs substantially across states. As Table 2 shows, this term yields large and highly significant coefficients for Texas and Georgia, but its effects in South Carolina, North Carolina, and Oklahoma are small and insignificant. There are likely several reasons for why the interaction term fails to yield positive and statistically significant results in the regressions for these three states. To begin with, it is important to bear in mind that the term measures the impact of incumbent ideology on electoral incongruence only among districts with Democratic incumbents running for re-election. This means that the sample size of districts upon which it is based is considerably smaller than the total number of districts included in the regression, making the term more vulnerable to outlier values. In the North Carolina regression, for example, there are only seventeen districts with Democratic incumbents in the dataset. A close examination of these districts revealed two incumbents with highly negative ideology values (i.e., quite liberal) whose re-election races nevertheless yielded high electoral incongruence scores. Removing these two outlier cases from the regression would have caused the coefficient for the interaction term to change substantially. It also appears that the size and significance of the Democratic incumbent-ideology interaction term is influenced by the ideological distribution of Democratic incumbents running for re-election in each state. In Oklahoma, for example, the average Democratic incumbent had an ideology score of -0.13 (slightly left-of-center) and the standard deviation of ideology scores was relatively small, while in Texas the average Democratic incumbent had an ideology score of -0.61 (substantially further to the left) and the standard deviation of ideology scores was much larger. Thus, the comparatively small effect of Democratic legislator ideology on electoral incongruence in Oklahoma can be explained by the fact that relatively little substantive variation in ideology among Democratic legislators running for re-election in 2000 existed in the state. 


\section{What Caused the Decline of Electoral Incongruence in the American South?}

As noted earlier, electoral incongruence in the American South appears to be largely a thing of the past. Results from recent elections strongly suggest that extensive ticket-splitting between Republican presidential candidates and Democratic state legislative candidates has recently experienced a dramatic drop in the region. This insight naturally raises the question of what caused electoral incongruence's decline. Though providing a full answer to this question would require a highly detailed examination of individual states that is beyond the scope of this paper, it is possible to begin the process of answering it here by considering some of the most likely contributing factors.

One factor that seems likely to have influenced the decline of electoral incongruence in the South is the voluntary retirement of longstanding conservative Democratic legislative incumbents. As this study has shown, the incumbency advantage helped many Democratic state legislators outperform their party's presidential nominees, especially if they had compiled conservative voting records in the statehouse. When such incumbents retired, voters who had previously split their tickets across state and federal offices would have had less reason to do so, and widespread electoral incongruence would have declined as a result.

Electoral incongruence may have also declined as a result of decreased support for Democratic incumbents in conservative districts formerly displaying high incongruence levels. Such a decrease could have come about for a variety of reasons. First, voters accounting for much of the support for such incumbents in the late 1990s and early 2000s (i.e., whites who came of age before the 1960s) may have declined as a share of the electorate due to the effects of generational replacement. Second, increased alienation from the national Democratic Party may have caused conservative southern whites of all ages to abandon their ticket-splitting habits, particularly in highly nationalized elections such as occurred in 2010 and 2012. Such an explanation would be consistent with much recent literature emphasizing a long-term nationwide pattern of "partisan sorting" in which voters increasingly abandon ancestral party attachments in order to support the political party to which they are ideologically closest (see, e.g., Abramowitz and Saunders 1998; Abramowitz and Saunders 2008; Fiorina et al 2008). ${ }^{13}$ Importantly, this sorting process has been especially pronounced in the American South (particularly among conservative whites who have switched from the Democratic to the Republican Party) and has amplified substantially during the Obama presidency, the time period in which levels of electoral incongruence in the South experienced their most significant drop (Knuckey 2001; Knuckey 2006; Jacobson 2013; Jacobson 2015). Third, over the last several decades, many southern states (including some of the ones studied in this article) have experienced a significant in-migration of upscale white northerners who lack the ancestral attachment of white southerners to the Democratic Party (Scher 1997; Lublin 2004). These new southerners may have split their tickets between Republican presidential candidates and Democratic state legislative candidates at lower rates than native southerners, causing overall levels of electoral incongruence to decline.

A final factor that may have caused the decline of electoral incongruence is redistricting. The redrawing of state house districts following the 2010 Census may have led to a decline in electoral incongruence through two mechanisms. First, if (as seems likely) many of the districts exhibiting electoral incongruence in the 2000s were based in slow-growing areas, legislatures may have found it necessary to combine large portions of such districts with other areas after the 
2010 Census in order to comply with the judicially-mandated requirement that state legislative districts have equal populations. Second, whereas Republicans controlled none of the five states under examination during the redistricting that followed the 2000 Census, they controlled all five in the redistricting that followed the 2010 Census. With control of the redistricting process in their hands for the first time since reconstruction, Republicans in each of these states may well have targeted the few remaining Democratic legislators representing constituencies supporting Republican presidential candidates by dismantling their districts. Under both situations, Democratic legislators representing districts supporting Republican presidential candidates would have been faced with largely new constituencies with whom they had no pre-established relationships and thus a very limited ability to cultivate a "personal vote." These legislators would have had a much harder time winning in their redrawn districts, potentially causing many of them to retire rather than seek re-election in 2012. Thus, while redistricting cannot explain the decline in electoral incongruence that occurred prior to 2012, it can perhaps explain some of the decline that has occurred from then onwards. ${ }^{14}$

To examine the relative importance of the three aforementioned explanations, I trace the electoral trajectories of state house districts exhibiting incongruent election results in 2004 (i.e., a Democrat elected against a Republican challenger at the same time as a majority of the district's voters support George W. Bush against John Kerry) in each of the five states, from 2004 until the present. Doing so necessitates linking state house districts across two redistricting cycles. I accomplish this via relating district boundaries used before and during the 2012 elections in ArcGIS to determine how populations were redistributed from one set of districts to another. ${ }^{15}$ When over $50 \%$ of the population within a pre-2012 district was drawn into a post-2012 district and over $50 \%$ of the population of the post-2012 district came from the aforementioned pre-2012 district, the post-2012 district was deemed to be the "child" of the pre-2012 district. ${ }^{16}$ Pre-2012 districts without any "children" are those that I label "dismantled" as a result of the 2011 redistricting.

Figure 3 (below) presents a visual representation of the electoral trajectories of state house districts displaying incongruent results in 2004 (hereinafter referred to as "EI04 districts") in each of the five states. The horizontal dashed line in each of the five graphs represents the percentage of EI04 districts in each state's lower chamber. The red filling within each graph represents the percentage of EI04 districts that came to be represented by Republicans in elections after 2004, while the gray filling represent the percentage of EI04 districts that were dismantled as a result of the 2011 redistricting. Lastly, the plot presents two solid lines: the orange line with circular markers represents the percentage of EI04 districts in a given post-2004 election in which Republicans won open-seat contests, and the yellow line with diamond-shaped markers represents the percentage of EIO4 districts in a given post-2004 election in which Republican challengers defeated Democratic incumbents. 


\section{Figure 3: The Electoral Trajectories of State House Districts Exhibiting Incongruent Election Results in 2004 (EI04 Districts)}

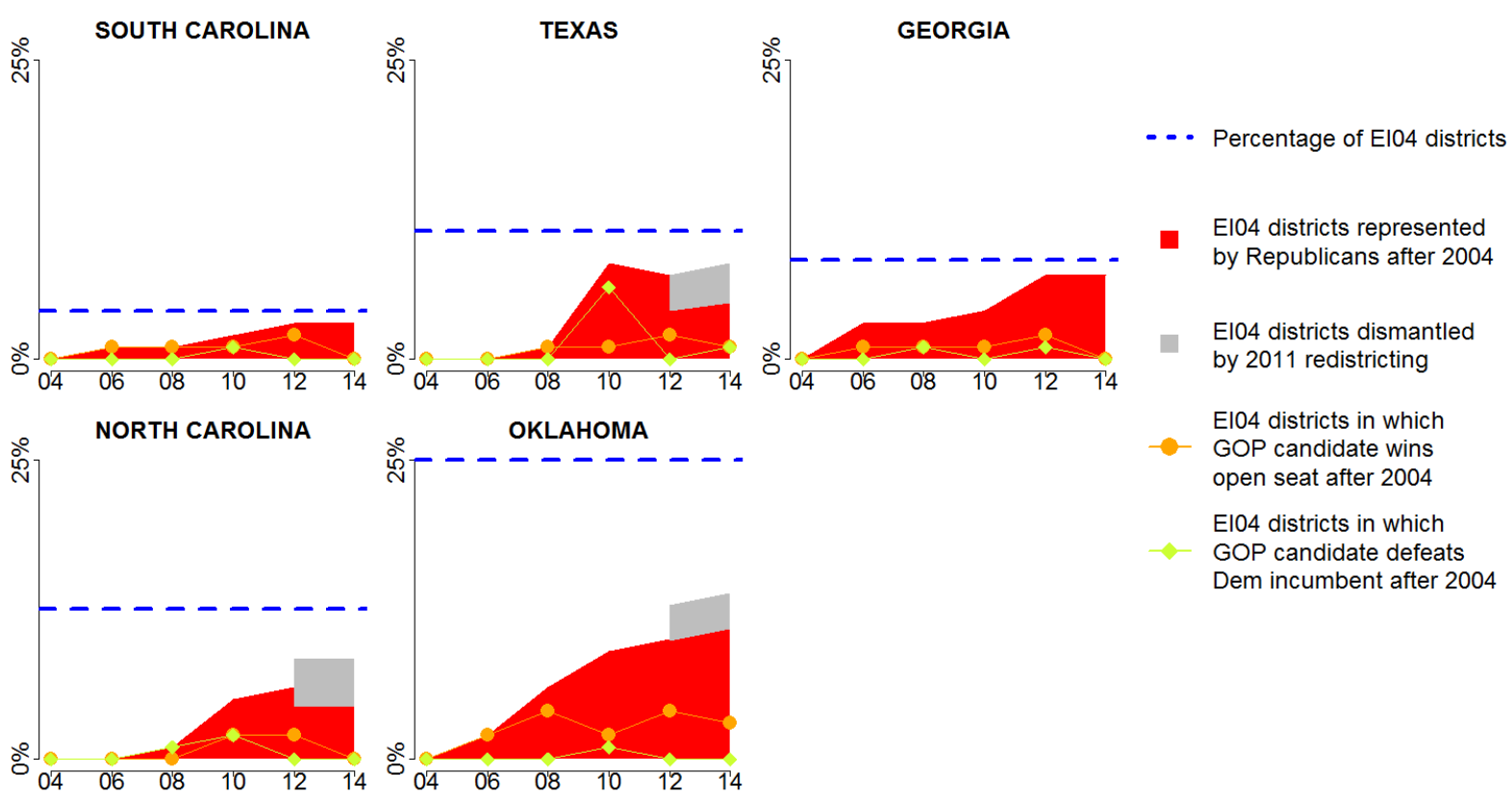

Figure 3 demonstrates several important findings, including that, in most of the states and across most of the individual elections, Republicans were more likely to pick up EI04 districts via winning open seats than via defeating incumbent Democrats. Indeed, in Oklahoma, nearly all of the gains that the GOP has made in EI04 districts since 2004 have come about when longstanding Democratic incumbents retired and were replaced by Republicans. This is also largely the case, though to a somewhat lesser extent, in Georgia and South Carolina. ${ }^{17}$ The greater importance of open-seat contests in these states suggests that the retirement of longstanding Democratic incumbents has been a more consequential overall factor in contributing to the decline of electoral incongruence in the South than decreased support for Democratic incumbents has been.

While open-seat contests tend to produce more Republican pickups than do incumbent defeats across individual elections in all five states, there is a single state - Texas - where the overall importance of incumbent defeats to GOP gains in EI04 districts is substantially higher than that of open-seat wins. This is almost entirely due to the influence of the 2010 election, in which nine longstanding incumbents from EI04 districts lost their re-election bids. Many of these incumbents had been in office for well over a decade and had repeatedly triumphed over Republican challengers in tough political environments, but in 2010 each and every one of them was defeated. The sudden losses of so many veteran Democratic lawmakers in Texas in a single election year suggests that these lawmakers owe their defeats more to the decisions of voters to no longer split their tickets than to the generational replacement of older white ticket-splitters. After all, a generational replacement account of such losses would suggest that they should have occurred far more gradually than they did. Instead, it seems more likely that anger with (and alienation from) the national Democratic Party in Texas in 2010 caused voters in many EI04 
districts to break with the state legislative Democrats that they had supported so many times before, thereby leading to the demise of electoral incongruence in the state. ${ }^{18}$

Finally, the results displayed in Figure 3 suggest that the 2011 redistricting played at most a minimal role in the decline of electoral incongruence in the South. For example, in Texas, roughly one-third of EI04 districts were dismantled in the 2011 redistricting, but all of these districts were ones that the GOP captured by defeating Democratic incumbents in 2010 , suggesting that a key reason these districts were dismantled may have been slow population growth. Because Republicans won these districts before the 2011 redistricting, one cannot attribute the decline in electoral incongruence to the redistricting itself (indeed, given the fact that Republicans who capture districts formerly exhibiting high levels of electoral incongruence usually have no trouble winning their re-election bids, it is quite likely that the Republicans representing the dismantled EI04 districts between 2010 and 2012 would have easily won their re-election bids in those same districts in 2012). In North Carolina, a similar percentage of EI04 districts were dismantled in the 2011 redistricting, but two-fifths of these districts were captured by Republicans in 2010. The Democrats representing the remaining EI04 districts that were dismantled may well have been targets of gerrymandering efforts in 2011, but it is worth noting that all but one of these Democrats sought re-election in new districts in 2012 and won.

Likewise, a small number of EI04 districts represented by Democrats were dismantled in the 2011 redistricting in Oklahoma, but the Democrats representing these districts all ran for and won reelection in new districts.

It is possible that the definition of a dismantled district used in this article is simply too crude to capture the impact of redistricting on electoral incongruence, and that a more detailed analysis of the redistricting process in each of the five states might uncover greater evidence that Republicans successfully targeted Democrats elected from EI04 districts through this process. It is noteworthy that, in Georgia and North Carolina in particular, a fairly large number of Democrats who were elected from EI04 districts in 2010 decided to retire rather than seek reelection in 2012, despite the fact that their districts did not meet the criteria that were used in this paper for being considered dismantled. Some of these legislators were fairly old and may have been likely to retire irrespective of the outcome of the 2011 redistricting, but for the remainder, it is possible that, though their districts were not thoroughly ripped apart, they were still sufficiently altered to convince these members not to take the risk of running for reelection. However, the decisions of these legislators not to seek reelection in 2012 may also have been driven by the fact that the GOP had come to command dominant majorities in their chambers after the 2010 elections, and they had little interest in continuing to serve in the legislature as members of the minority party. Interestingly, in the wake of the 2010 elections, two Democrats representing EI04 districts in Georgia switched parties, and a third announced during the 2012 campaign that he would caucus with Republicans should he be re-elected. The extent to which the prospects or reality of GOP-controlled redistricting affected these legislators' party switching decisions is unclear. A more in-depth examination of the 2011 redistricting and how Democratic legislators like these responded to it could reveal more about the extent to which redistricting contributed to the decline of electoral incongruence in the South. 


\section{Conclusion}

The results of this article describe and explain an important and underexplored aspect of partisan change in the American South. From a purely descriptive standpoint, they demonstrate that substantial electoral incongruence existed in five southern states throughout the 1990s and 2000s, that it partially accounted for the delayed ascendancy of Republicans in the lower legislative chambers of these states, and that it has experienced a sharp decline in recent elections. From an explanatory standpoint, they clearly show that the continued presence of electoral incongruence through the first decade of the $21^{\text {st }}$ century was partly owing to the political resilience of conservative incumbent Democrats, and they strongly suggest that it was also a result of split-ticket voting among older white voters and those living in rural areas. Finally, the results demonstrate that the most important cause of the decline of electoral incongruence in the South was the voluntary retirement of longstanding Democratic state legislators, but that a plunge in support for incumbents Democrats during the 2010 elections also played an important role (especially in Texas). The 2010 losses of many longstanding right-ofcenter Democrats can be interpreted as the final stage of a decades-long process of partisan sorting in the southern electorate, resulting in conservative voters supporting Republican candidates for races at all levels of government.

These findings are important for scholars of southern politics for a number of reasons. To begin with, they explain the existence and decline of electoral incongruence, a phenomenon that has been previously noted but never rigorously analyzed by political scientists studying the South. Perhaps more importantly, they provide one of the first accounts of the $21^{\text {st }}$-century Republican consolidation of power in southern legislatures. While scholars of southern politics (as well as American politics writ large) have long been interested in the post-1960s partisan transformation of the South, few have closely examined how this transformation eventually resulted in the Republican takeover of nearly all of the region's statehouses. The importance of this final stage of the southern realignment has become increasingly apparent in recent years, as southern states under firm Republican control for the first time since Reconstruction have moved state policy substantially to the right in areas such as voting laws, abortion, welfare, education funding, and others. The findings of this article provide new insights into why it took so long for Republicans to consolidate power in southern state legislatures, as well as how they were finally able to do so.

While the headway made by this study is surely important, more work needs to be done in order to provide a fuller account of the delayed Republican takeover of southern legislatures. To begin with, attention needs to be given to southern states (including Alabama, Louisiana, Mississippi, and Virginia) that do not hold their state legislative elections in presidential election years or even (in the cases of the latter three states) in congressional midterm election years. It is quite possible (indeed likely) that the separation of state legislative elections from federal elections in these states helped to insulate Democratic legislators from national electoral trends working in favor of Republicans. Additional, a more wide-ranging study of delayed Republican gains in southern legislatures would need to more carefully consider the interaction between electoral incongruence and Republican non-contestation of state legislative elections. While this study has largely sought to separate these two phenomena, it cannot be denied that they are to 
some degree interconnected since they are both affected by the organizational strength of local parties.

Beyond its importance for the study of southern politics, this article also has significant implications for the larger study of American state politics as well. Since at least the days of V.O. Key, state politics scholars have been concerned with the question of how much autonomy state elections enjoy from the dynamics of national party politics (Key 1956; Bibby 1983; Campbell 1986; Stein 1990; Gimpel 1996; Brown and Bruce 2002; Brown and Bruce 2008; Bulman-Pozen 2014). While answers to this question have varied to some extent, the general consensus has been that state elections enjoy little autonomy from national politics on the whole but that significant regional variations exist, with the South and (to a lesser extent) the Mountain West being regions that have historically evinced substantial differences between the partisan cleavages evident in their state and federal elections. The results of this study strongly suggest that, with respect to at least the South, this is no longer the case. Indeed, all indications are that, during the years of the Obama presidency, the southern states joined the rest of the country in bearing partisan cleavages that are essentially identical across elections to different levels of government. Given that the social groups formerly responsible for creating high levels of electoral incongruence in the South (i.e., older whites and rural voters) constitute progressively smaller shares of the southern electorate with every passing election cycle, it seems very unlikely that the phenomenon will return to the region in the future. Thus, one of the few remaining pockets of state electoral autonomy in the country has disappeared, with little to no prospects for resurrection. In the early $21^{\text {st }}$ century, state legislative elections are therefore likely to be fought against the backdrop of a uniformly national political context. 


\section{References}

1. Abramowitz, Alan I. and H. Gibbs Knotts. 2006. "Ideological Realignment in the American Electorate: A Comparison of Northern and Southern White Voters in the PreReagan, Reagan, and Post-Reagan Eras." Politics and Policy 34(1): 94-108.

2. Abramowitz, Alan I. and Kyle L. Saunders. 1998. "Ideological Realignment in the U.S. Electorate." Journal of Politics 60(3): 634-652.

3. Abramowitz, Alan I. and Kyle L. Saunders. 2008. "Is Polarization a Myth?" Journal of Politics 70(2): 542-555.

4. Aistrup, Joseph A. 1996. The southern Strategy Revisited: Republican Top-Down Advancement in the South. Lexington, KY: University of Kentucky Press.

5. Barth, Jay. 1992. "Dual Partisanship in the South: Anachronism, or a Real Barrier to Republican Success in the Region?” Midsouth Political Science Journal 13: 487-500.

6. Bean, Clive S. and Martin P. Wattenberg. 1998. "Attitudes Toward Divided Government and Ticket-Splitting in Australia and the United States." Australian Journal of Political Science 33(1): 25-36.

7. Bibby, John F. 1983. "Patterns in Midterm Gubernatorial and State Legislative Elections." Public Opinion 6: 41-46.

8. Brambor, Thomas, William Roberts Clark, and Matt Golder. 2006. "Understanding Interaction Models: Improving Empirical Analyses.” Political Analysis 14: 63-82.

9. Brown, Robert D. and John M. Bruce. 2002. "Political Parties in State and Nation: Party Advantage and Party Competition in a Federal Setting." Party Politics 8: 635-656.

10. Brown, Robert D. and John M. Bruce. 2008. "Partisan-Ideological Divergence and Changing Party Fortunes in the States, 1968-2003: A Federal Perspective." Political Research Quarterly 61(4): 585-597.

11. Bullock, Charles S. 1988. "Creeping Realignment in the South." In The South's New Politics: Realignment and Dealignment, edited by R.H. Swansbrough and D.M. Brodsky, 220-237. Columbia, SC: University of South Carolina Press.

12. Bulman-Pozen, Jessica. 2014. "Partisan Federalism." Harvard Law Review 127 (4): 1077-1146

13. Burden, Barry C. and David C. Kimball. 1998. "A New Approach to the Study of TicketSplitting.” American Political Science Review 92(3): 533-544.

14. Campbell, James E. 1986. "Presidentail Coattails and Midterm Losses in State Legislative Elections.” American Political Science Review 80(1): 45-63.

15. Carmines, Edward G. and Harold W. Stanley. 1990. "Ideological Realignment in the Contemporary South: Where Have All the Conservatives Gone?" In The Disappearing South: Studies in Regional Change and Continuity, edited by L.W. Moreland and T.A. Baker. Tuscaloosa, AL: University of Alabama Press.

16. Carson, Jamie L., Michael H. Crespin, Charles J. Finocchiaro, and David W. Rhode. 2007. "Redistricting and Party Polarization in the U.S. House of Representatives." American Politics Research 35(6): 878-904. 
17. Carey, John M., Richard G. Niemi, and Lynda W. Powell. 2000. "Incumbency and the Probability of Reelection in State Legislative Elections." Journal of Politics 62(3): 671-700.

18. Converse, Philip E. 1966. "On the Possibility of a Major Realignment in the South." In Elections and the Political Order, edited by A. Campbell. New York: John Wiley.

19. Cox, Gary W. and Scott Morgenstern. 1993. "The Increasing Advantage of Incumbency in the U.S. States." Legislative Studies Quarterly 18(4): 495-514.

20. Delli Carpini, Michael X. and Scott Keeter. 1996. What Americans Know About Politics and Why It Matters. New Haven, CT: Yale University Press.

21. Fiorina, Morris P., Samuel A. Abrams, and Jeremy C. Pope. 2008. "Polarization in the American Public: Misconceptions and Misreadings." Journal of Politics 70(2): 556-560.

22. Gaddie, Ronald Keith and Gary W. Copeland. 2003. "Oklahoma: The Secular Realignment Continues." In The New Politics of the Old South, edited by Charles S. Bullock III and Mark J. Rozell. Lanham, MD: Rowman and Littlefield.

23. Gelman, Andrew and Jennifer Hill. 2007. Data Analysis Using Regression and Multilevel/Hierarchical Models. New York: Cambridge.

24. Gimpel, James G. 1996. National Elections and the Autonomy of State Party Systems. Pittsburgh, PA: University of Pittsburgh Press.

25. Grofman, Bernard and Thomas L. Brunell. 2005. "The Art of the Dummymander: The Impact of Recent Redistricting on the Partisan Makeup of Southern House Seats." In Redistricting in the New Millennium, edited by Peter F. Galderisi. Lanham, MD: Lexington Books

26. Hadley, Charles D. 1985. "Dual Partisan Identification in the South." Journal of Politics 47: 254-268.

27. Hillygus, D. Sunshine and Todd Shields. 2008. "Southern Discomfort? Regional Differences in Voter Decision Making in the 2000 Presidential Election." Presidential Studies Quarterly 38 (3): 506-520.

28. Jacobson, Gary C. 2013. "How the Economy and Partisanship Shaped the 2012 Presidential and Congressional Elections." Political Science Quarterly 128 (1): 1-38.

29. Jacobson, Gary C. 2015. "Obama and the Nationalization of Electoral Politics in 2012." Electoral Studies 40 (4): 471-481.

30. Key, V.O. 1956. American State Politics. New York: Knopf.

31. Klarner, Carl, William Berry, Thomas Carsey, Malcolm Jewell, Richard Niemi, Lynda Powell, and James Snyder. 2013. State Legislative Election Returns (1967-2013). ICPSR34297-v1. Ann Arbor, MI: Inter-university Consortium for Political and Social Research [distributor], 2013-01-11. doi:10.3886/ICPSR34297.v1.

32. Knuckey, Jonathan. 2001. "Ideological Realignment and Partisan Change in the American South, 1972-1996.” Politics and Policy 29(2): 337-358.

33. Knuckey, Jonathan. 2006. "Explaining Recent Changes in the Partisan Identifications of Southern Whites." Political Research Quarterly 59(1): 57-70.

34. Lewis-Beck, Michael and Richard Nadeau. 2004. "Split-Ticket Voting: The Effects of Cognitive Madisonianism.” Journal of Politics 66 (1): 97-112. 
35. Lublin, David. 2004. The Republican South: Democratization and Partisan Change. Princeton, NJ: Princeton University Press.

36. Lublin, David, and D. Stephen Voss. 2001. "Federal Elections Project." American University, Washington, DC and the University of Kentucky, Lexington, KY.

37. McDonald, Michael P. 2014. "Presidential Vote within State Legislative Districts." State Politics and Policy Quarterly 14(2): 196-204.

38. McKee, Seth C. 2010. Republican Ascendancy in southern U.S. House Elections. Boulder, CO: Westview Press. 1

39. McKee, Seth C. 2013. "Political Conditions and the Electoral Effects of Redistricting." American Politics Research 41(4): 623-650.

40. McKee, Seth C. and Melanie J. Springer. 2015. "A Tale of 'Two Souths': White Voting Behavior in Contemporary Southern Elections." Social Science Quarterly 96(2): 588-607.

41. Petrocik, John R. 1987. "Realignment: New Party Coalitions and the Nationalization of the South." Journal of Politics 49(2): 347-375.

42. Schaller, Thomas F. 2008. Whistling Past Dixie: How Democrats Can Win Without the South. New York: Simon and Schuster.

43. Scher, Richard K. 1997. Politics in the New South: Republicanism, Race, and Leadership in the Twentieth Century. Armonk, NY: M.E. Sharpe.

44. Shor, Boris and Nolan McCarty. 2011. "The Ideological Mapping of American Legislatures." American Political Science Review 105(3): 530-551.

45. Stein, Robert M. 1990. "Economic Voting for Governor and U.S. Senator: The Electoral Consequences of Federalism." Journal of Politics 52(1): 29-53.

46. Steenbergen, Marco R. and Bradford S. Jones. 2002. "Modeling Multilevel Data Structures.” American Journal of Political Science 46(1): 218-237. 


\section{Appendix: Miscellaneous Information on Data Sources and Procedures}

\section{Precinct-Level Election Data}

Precinct-level election data for the five states included in the analysis were collected from a variety of sources. The table below provides an overview of the various electoral data sources:

\begin{tabular}{|c|c|}
\hline State & Precinct-Level Election Data Sources \\
\hline South Carolina & South Carolina State Election Commission (www.scvotes.org) \\
\hline Texas & Texas Legislative Council (www.tlc.state.tx.us) \\
\hline Georgia & $\begin{array}{l}\text { Georgia Reapportionment office (http://www.legis.ga.gov/Joint/ } \\
\text { reapportionment) }\end{array}$ \\
\hline North Carolina & North Carolina State Board of Elections (http://www.ncsbe.gov/ncsbe/) \\
\hline Oklahoma & $\begin{array}{l}\text { - } 2000 \text { data from Lublin and Voss, "Federal Elections Project" } \\
\text { (http://www.american.edu/spa/ccps/Data-Sets.cfm) } \\
\text { - } 2004 \text { and } 2008 \text { presidential election data (used only for calculating } \\
\text { presidential vote by state legislative district) from the Harvard } \\
\text { Election Data Archive (http://projects.iq.harvard.edu/eda) } \\
\text { - } 2012 \text { data from Oklahoma State Election Board (www.ok.gov/ } \\
\text { elections) }\end{array}$ \\
\hline
\end{tabular}

\section{Aggregating Precinct-Level Presidential Election Data to the State House District Level}

Aggregating precinct-level election data to the state house district level is, in theory, easily conducted by summing together election data from precincts inside the same house district. In practice, the process is complicated by the presence of precincts whose boundaries overlap with more than one state house district (so-called "split precincts") and election tallies that are sometimes reported in special "non-polling place" categories such as provisional votes, absentee votes, etc. (McDonald 2014, p. 198).

In Texas, where few precincts are split between house districts and votes not cast in polling places are allocated to the vote totals of the precinct where the voter resides, the aggregation process proved easiest. While some Texas counties only report election data at the county level, this was not a problem since, in almost all cases, these counties were contained within a single house district.

In South Carolina, Georgia, North Carolina, and Oklahoma, on the other hand, the situation was considerably more complex due to the presence of a significant share of split precincts (never more than $15 \%$ of all precincts) and the reporting of many votes in non-polling place categories. Excluding votes in split precincts or non-polling place votes from the aggregation process could lead to significant biases in the aggregated presidential vote totals. To overcome the aforementioned issues, I calculated the percentage of voters in split precincts/nonpolling places who voted in a given state house election. I then apportioned presidential votes in split precincts/non-polling places to house districts on the basis of the foregoing percentages. 
While not perfect, this procedure assures that the aggregated presidential election data in these states have only a minimal amount of bias.

Aggregating precinct-level data in Oklahoma for the 2004 and 2008 elections proved still more challenging since only presidential election data from geographical precincts were available. The district-level presidential vote in Oklahoma for 2004 and 2008 thus does not include non-polling place data. Any bias incurred as a result is likely to be only apparent in state house districts located in Oklahoma and Tulsa counties, since they are the only counties in the state that are known to report election results in non-polling place categories.

\section{Estimating Census-Based Demographic Data at the Precinct Level Using ArcGIS}

As mentioned in the text of the article, the precinct-level demographic data used in the article's multivariate analyses needed to be estimated since precincts are generally not coterminous with any Census geography and Census data thus cannot be easily aggregated to the precinct level.

To estimate demographic data at the precinct level, I collected 2000 Census data at the block group level from the U.S. Census website (http://factfinder.census.gov) and merged it with shapefiles of 2000 Census block groups. I then located shapefiles of precincts that were in place as close to the November 2000 election as possible for each of the five states from a variety of sources. Using ArcGIS, I intersected the boundaries of the Census block groups with the boundaries of the precincts and calculated the areas of the block group-precinct intersections. Next, I calculated the area of each intersection as a proportion of the total area of each block group of which it was constituted, and apportioned Census block group demographic data to precincts on the basis of these proportions. For example, if the intersection between Census Block Group A and Precinct B accounted for 70\% of Census Block Group A's area, then 70\% of Census Block Groups A's demographic data were apportioned to Precinct B. Demographic data on age, race, and urban/rural residence were then summed together by precinct and relevant percentages were calculated.

To examine the extent to which the procedure described above yields reliable estimates of precinct-level demographics, I took advantage of the fact that two states in my sample (South Carolina and North Carolina) release the racial breakdowns of registered voters in their precincts. It was thus possible to compare the percentage of white registered voters as derived directly from state data sources with the percentage of whites in the voting-eligible population (i.e., persons aged 18 and over) as derived from my estimation procedure. The comparison suggested that my estimates are quite reliable. For example, the correlation between these two statistics across precincts was 0.91 in South Carolina and 0.93 in North Carolina. Given that racial breakdowns in voter registration are likely to differ slightly from racial breakdowns in the voting-eligible population, one should expect that the association between these two variables will be very strong but not perfect. 


\section{Descriptive Statistics for Variables included in the Multivariate Analyses}

Below is a table presenting basic descriptive statistics for the continuous variables that were used in the multivariate analysis combining data from all five states.

Variable

Mean

St Dev

Min

Max

Precinct-Level:

Electoral Incongruence

11.0

13.4

$-39.3$

76.1

$\%$ white and aged 18-64

(among eligible voters)

58.1

18.3

0.4

88.8

$\%$ white and aged 65 and over

13.6

7.0

0.0

52.2

(among eligible voters)

$\%$ rural

51.6

43.8

0.0

100.0

District-Level

Democratic incumbent (dummy)

(115 districts coded 1, 123 coded 0 )

Dem incumbent * incumbent

Ideology

$-0.15$

0.30

$-1.34$

0.52

GOP incumbent (dummy)

(86 districts coded 1,152 coded 0 )

GOP Incumbent *

incumbent ideology

$0.36 \quad 0.52$

0.0

1.89

Note that descriptive statistics for the incumbency-ideology interaction terms above include 0 values for all districts not featuring Democratic (Republican) incumbents. The "pure" descriptive statistics for legislator ideology (i.e., only districts with Democrat or Republican incumbents) are as follows.

\begin{tabular}{lllll} 
Variable & Mean & St Dev & Min & Max \\
\hline & & & & \\
Democratic incumbent ideology & -0.31 & 0.36 & -1.34 & 0.52 \\
Republican incumbent ideology & 1.00 & 0.31 & 0.25 & 1.89 \\
& & & & \\
\hline
\end{tabular}




\section{Relating State House Districts across Redistricting Cycles}

In order to relate state house districts from before and after the 2011 redistricting, I downloaded three sets of shapefiles from the U.S. Census shapefile clearinghouse (https:// www.census.gov/geo/maps-data/data/tiger-cart-boundary.html): shapefiles of pre-2012 districts, shapefiles of 2012 districts, and shapefiles of Census block groups used in the 2010 Census. Each shapefile was added to the ArcGIS workspace and then the following steps were taken: 1) the pre-2012 and 2012 district boundaries were intersected 2) Census block group populations inside a given district intersection were summed together using the "spatial join" procedure; 3) for all pre-2012 and 2012 districts, the percentages of their total populations drawn from the various district intersections were calculated. 


\section{Endnotes}

${ }^{1}$ Electoral contestation in the South has generally been studied in earlier time periods, and usually (though not always) for congressional rather than state legislative races.

${ }^{2}$ To be sure, there were election years during the 1960s and 1970s when Republican contestation of southern state legislative races spiked. The most prominent example is 1968, when national Republicans made a concerted effort to increase contestation in state and local elections in the region. I thank an anonymous reviewer for this insight.

${ }^{3}$ Other southern states were not included either because they do not hold their state legislative elections during presidential years, or because a variety of technical or data-related issues prevented their inclusion in the project. For literature on the distinction between the Deep South and the Rim South, see McKee and Springer 2015. For an argument that Oklahoma, despite its debatable status as a southern state, merits being considered part of the south in studies of American party politics, see Gaddie and Copeland 2003.

${ }^{4}$ While comparing state legislative election results to U.S. House election results at the precinct level might be a worthwhile potential endeavor, it is methodologically very difficult due to a variety of problems, including uncontested seats and precincts that are split between districts at both levels.

${ }^{5} 1996$ scatterplots for North Carolina, Georgia, and Oklahoma are not included due to unavailability of precinctlevel state legislative election data (the same goes for Oklahoma in 2004 and 2008). The scatterplots exclude precincts not featuring a state legislative election that was contested by both major parties, the far smaller number of precincts that were split between two state house districts, and the even smaller number of precincts in which less than ten votes were cast for either president or state representative. The 2000 plot for North Carolina also excludes precincts from multimember districts due to difficulties in calculating electoral incongruence in such districts (until 2002, the North Carolina House was divided into 98 districts, 81 of which were single-member and 19 of which were multimember).

${ }^{6}$ Because of differences in the way states report election results, the process of aggregating precinct-level presidential election data to state house district boundaries varied for each state in this study. The aggregation process was a relatively simple exercise for Texas but it posed substantial (though not insurmountable) obstacles in the other states. I discuss these challenges and how I deal with them in the appendix.

${ }^{7}$ All of the state house districts won by Republicans in 2000 in Texas were also won by Republican presidential candidate George W. Bush, and across the states and elections in the sample, the percentage of districts won by Democratic presidential candidates and Republican state house candidates is usually zero and never rises above 2.5\%. Thus, in the American South during the 1990s and 2000s, electoral incongruence almost always goes in one direction.

${ }^{8}$ The importance of electoral incongruence in Oklahoma in 2000 and 2004 is particularly impressive. In both of these election years, seats that Democratic candidates won against Republican challengers at the same time as their districts supported Republican George W. Bush for president accounted for a staggering 25\% of all Oklahoma House seats.

${ }^{9}$ Because precincts are the smallest units of aggregation available in American electoral studies, they are the best possible aggregate units with which to test explanations of voting behavior. While my account of electoral incongruence in the South would be ideally tested using individual-level data from surveys of southern voters in the 1990s and early 2000s, such data are simply unavailable because: (1) most state and national polls from this time period did not ask about state legislative vote intent; (2) even in cases in which state legislative vote intent was asked, sample sizes are never large enough and details of the geographical location of survey respondents are never fine-grained enough to allow for inferences concerning district-level effects (such as incumbency and incumbent ideology) on vote choice. Consequently, it is impossible to rigorously test my account with individual-level data.

10 The ideology score of each legislator in the dataset was subtracted by 0.016 -- the score for the mean state legislator nationwide - so that the mean score in the adjusted scale would be 0 . 
${ }^{11}$ Shor and McCarty use surveys of state legislative candidates and roll-call voting data to place nearly all state legislators between 1993 and 2011 on the same ideological scale. Readers will note that I include the interactions of legislator ideology with the incumbency variables in the model without including the constitutive ideology term, something methodologists usually recommend against doing. However, as Brambor, Clark, and Golder (2006, p. 66) point out, there can be "rare circumstances" in which omitting the constitutive term is appropriate. In particular, when researchers have "a strong theoretical expectation that the omitted variable... has no effect on the dependent variable in the absence of the other modifying variable," omitting the term is acceptable. That is the case here, since there is absolutely no reason to believe that the ideology of an incumbent legislator should have any effect on state legislative election outcomes if the incumbent is not a candidate for re-election.

${ }^{12}$ As Gelman and Hill note, this model specification is identical to a "mixed effects" model in which error terms vary across state legislative districts. The multilevel model was estimated using the lme4 package in R.

${ }^{13}$ While there is intense disagreement among scholars over whether the American public has polarized along party lines (see, e.g., Abramowitz and Saunders 2008; Fiorina et al 2008), scholars appear to be in general agreement that the sorting process has occurred, at least to some extent.

${ }^{14}$ Indeed, the ill-fated efforts by Democratic majorities in southern legislatures to insulate Democrats from partisan trends via redistricting in the decades prior to 2010 (nicknamed "dummymanders" by Grofman and Brunell) underscore the limited impact of redistricting on the trends discussed in this paper. While redistricting can be used to advance or forestall partisan gains in a legislative body, the sources of such changes ultimately lie elsewhere and will almost always overwhelm the effects of redistricting in the long run (see, e.g., Grofman and Brunell 2005 and McKee 2013 for discussions of the interaction between redistricting and long-term political conditions).

15 See the methodological appendix for more about how this process was conducted.

16 This categorization is similar to one that was used by Carson et al 2007.

${ }^{17}$ In Georgia, party switching among Democrats representing EI04 districts constitutes an additional factor that played a role in the decline of electoral incongruence. In particular, after the 2004 elections, three Georgia legislators representing EI04 districts switched parties to join the new Republican majority in the state house of representatives. In 2006, these three legislators ran for re-election as Republicans rather than Democrats.

${ }^{18}$ This is not to suggest that the decline of the Democratic Party in the Texas Legislature is overwhelmingly the result of voter conversion during the Obama era. Quite to the contrary, the decline of Democratic dominance in the Texas statehouse was a decades-long process owing as much to the other factors discussed (e.g., generational replacement, the retirement of longstanding legislators, etc.) as to voter conversion. However, the sudden demise of so many longstanding Democratic legislators representing strongly Republican districts in 2010 does appear to be the result of voters switching to supporting Republican state legislative candidates due to anger with the national Democratic Party. 